\title{
Ssciendo
}

Ethics \& Bioethics (in Central Europe), 2021, 11 (1-2), 67-81

DOI:10.2478/ebce-2021-0004

\section{Freedom in the Age of surveillance capitalism: Lessons from Shoshana Zuboff Yevhen Laniuk ${ }^{1}$}

\begin{abstract}
The Age of surveillance capitalism is a profound economical, sociological, political, philosophical, and ethical work by the American author, Harvard University Professor Shoshana Zuboff. In this work, she analyzes the new economic system, which she calls "surveillance capitalism." This system revolves around the commodification of personal data, which allows human behavior to be predicted and "nudged" towards profitable ends. This system is historically unprecedented and has only become possible in the technological milieu of interconnected devices, which appeared in the $21^{\text {st }}$ century. In this article, I look at the issue of freedom in Zuboff's work. I argue that her understanding of freedom involves three ethical dimensions, namely privacy, autonomy, and authenticity. I take "surveillance capitalism" as a theoretical framework, in which I explore several ethical challenges to freedom in the digital age.
\end{abstract}

Keywords: surveillance capitalism, freedom, behavioral surplus, instrumentarian power, privacy, autonomy, authenticity.

\section{Introduction}

The digital age is allegedly the fourth stage of development of human civilization after the hunter-gatherer society, the agrarian, and industrial eras. Each of these eras were not only different from the standpoint of their economic, political, and social organization, but, most importantly, in terms of the existential condition of man. As the digital age unfolds, it carries both promises and threats to human existence. By comparison, the industrial age made our species, on average, richer, more individualistic, and more connected than in the previous agrarian era. However, as the Communist and Nazi totalitarian regimes testify, the brunt of its technological power was also turned against the human being. Today, we look to the promises of the digital age just as our ancestors looked to the hopes of the industrial. Therefore, it is vital to analyze its potential threats, including the ethical ones, which come along with the opportunities.

Freedom is a core ethical value. For Immanuel Kant, it is the source of morality. To act morally is to exercise freedom, while the only way to fully exercise freedom is to act morally (Rohlf, 2020). Can the digital age create circumstances that will threaten freedom on a mass scale? If yes, what will these circumstances be? I consider Shoshana Zuboff's concept of "surveillance capitalism" as a framework within which it is possible to explore several ethical challenges to freedom in the digital age.

Shoshana Zuboff is an American author, a Harvard University professor, social psychologist, and philosopher. She is the author of the books: In the age of the smart machine: the future of work and power (1988), The support economy: why corporations are failing individuals and the next episode of capitalism (2002) (in co-authorship with James Maxmin), and The age of surveillance capitalism: the fight for a human future at the new frontier of power (2019). The last book is Zuboff's most monumental piece, which integrates her lifelong themes: the digital revolution, economy in the $21^{\text {st }}$ century, and human existence in the digital age. In this work, she has presented a thorough analysis of a new economic phenomenon, which she calls "surveillance capitalism." This phenomenon is characterized by surveillance and prediction of human behavior in a technological milieu of interconnected devices. Zuboff's theoretical schema allows not only the workings of the economy to be interpreted, but also the human condition in the digital age, including the ethical value of freedom.

\footnotetext{
${ }^{1}$ Ivan Franko National University of Lviv (Ukraine); yevhen.lanyuk@lnu.edu.ua; Scopus ID: 57217255574
} 
In this article, I will explore the challenges to freedom that arise from Shoshana Zuboff's concept of surveillance capitalism. I will show that these challenges should be understood not so much as a political or economic, but more as an ethical issue. My goal is not to analyze this system empirically or examine how deeply it penetrates into society, but to take it essentially as a framework, in which I will consider a number of ethical challenges to freedom. The article is divided into three parts. In Part 1, I will look at Shoshana Zuboff's concept of surveillance capitalism and outline its basic features. In Part 2, I will delineate a few lines along which she interprets freedom. In Part 3, I will consider several ethical threats to freedom that proceed from the system of surveillance capitalism. Finally, in Conclusions, I will suggest some ways to consider the issue further.

\section{The logic of surveillance capitalism}

It would be no exaggeration to say that freedom is the central theme of The age of surveillance capitalism. If one dared to scale down this almost five-hundred-page book to a single sentence, that sentence most likely would be the following: "The essence of surveillance capitalism is the annihilation of freedom and its replacement by a machine-like certainty." This extraordinary annihilation does not have historical antecedents and cannot be tapered down to any of the known threats. It is only possible in the interconnected and highly dense network of apps and devices, which are simultaneously sensors and actuators. These sensors record human activity and piece together fragmented information about a person's behavior. This raw data is processed by machine intelligence and assembled into a model. Once this person's data is fed into this model of behavior, it will predict their future actions. Actuators aim to convert this knowledge into profit by "nudging" human choices toward outcomes that align with the interests of surveillance capitalists. As this system unfolds, it poses a threat to human freedom, replacing a person - a sovereign and autonomous decision-maker - with a kind of Pavlov's dog who is studied and conditioned by others.

Shoshana Zuboff's concept of surveillance capitalism revolves around two central concepts: behavioral surplus and instrumentarian power. The first concept refers to the practice of rendering human behavior as data and profiting from it, whereas the second indicates a specific type of power that operates through behavior modification.

In Karl Marx's economic theory, "surplus value" is the difference between the amount raised through the sale of a product and the amount it costs to the owner to manufacture that product. Zuboff writes about a new kind of surplus value, namely the "behavioral surplus," which she understands as behavioral information that goes beyond product or service use and instead is used to understand and predict human behavior. The manufacturers of digital products, including apps or websites, constantly get feedback data from their users, including clicks, spelling errors, browsing history, geolocation, etc. According to Zuboff, Google was the first to discover (around the early 2000s) that those "digital crumbs" contained valuable insights into human behavior and, thus, allowed it to be understood and predicted. It turned out that such knowledge was a goldmine. Not only was there a great demand for it among advertisers, but it also provided a constant and free of charge stream of behavioral information, which could be turned into a continuous flow of money. Human private experiences have, thus, become a means to others' commercial ends.

The tycoons of surveillance capitalism, including Google and Facebook, do not charge a fee for their services, despite being among the most valuable companies on earth. Instead most of their income flows from behavioral surplus, which they glean from their users, recycle through machine intelligence into prediction models, and sell those models in a new kind of marketplace, which the author calls the "behavioral futures market." At first, behavioral surplus was simply "found" as a by-product of users' online actions. Later, it was hunted aggressively and procured largely through surveillance. Once this economic logic had been discovered, 
competitive dynamics pushed others to follow, and the system of surveillance capitalism materialized. According to Zuboff, "even the most innocent-seeming applications such as weather, flashlights, ride sharing, and dating apps are 'infested' with dozens of tracking programs that rely on increasingly bizarre, aggressive, and illegible tactics to collect massive amounts of behavioral surplus ultimately directed at ad targeting" (Zuboff, 2019, chapter. 5).

Yet, she contends that this system is only incidentally about ads just as "Ford's new system of mass production was only incidentally about automobiles" (Zuboff, 2019, chapter 3). Instead "any actor with an interest in purchasing probabilistic information about our behavior and / or influencing future behavior [...] can play in markets where behavioral fortunes are bought and sold" (Zuboff, 2019, chapter 3). In a broad sense, surveillance capitalism is about buying and selling human futures.

Eventually, the goal of this system is not just to know what human beings will do now, soon, and later, but to put this knowledge into use by "nudging" them toward profitable ends. The term "nudging" was introduced by the American economist and 2017 Nobel Prize laureate Richard Thaler. According to Thaler, the knowledge of human psychology allows people to be prodded to make all kinds of decisions if the options are presented to them in the right way. One example is the university cafeteria manager who wants her customers to eat healthier food (Thaler \& Sunstein, 2003, p. 175). Knowing that the students do not have much time to deliberate between classes, she displays vegetables right at the entrance and puts cakes some distance away from their line of sight. With this trick, the clients of the cafeteria shifted to a healthier diet. The desired behavior resulted from the knowledge of their psychology combined with manipulation of the context in which the options were presented to them.

Zuboff discusses nudging as the central element of her concept of instrumentarian power. In general terms, power is the capacity to direct or influence the behavior of others. The Spanish sociologist Manuel Castells argues that historically there were two main types of power, namely coercive and persuasive power (Castells, 2017). The first type is body oriented. It is embodied in police and law-enforcement agencies and is exercised through instructions and prohibitions. The second type is mind oriented. It is embodied in propaganda and carried out through mind control. Instrumentarian power is neither body nor mind oriented. It does not prohibit anything, nor does it attempt to change its subjects. Instead, it operates in stealth (its subjects, for the most part, do not suspect that power is being exercised over them) and works via behavior modification. Yet, it is still power if power is understood as imposing one's will on others. The example of the students' diet clearly shows that the desired behavior resulted from the manager's will - not the will of the students.

According to Shoshana Zuboff, the digital realm has become an unprecedented playground of instrumentarian power. We live in a dense and highly saturated environment of digital devices, which continuously monitor human behavior and alter the settings in which it occurs in order to prod it to lucrative ends. The scope of behavior modification ranges from ads popping up on smartphone screens to remotely controlled machinery.

The hunt for behavioral surplus and instrumentarian power does not belong exclusively to the online world, but increasingly comes to define the physical world as well. Zuboff contends that "smart" objects, including cars, appliances, furniture, and even toys, all become means of surveillance and behavioral modification. She discusses the augmented reality game Pokémon Go, launched by Google's internal startup Niantic Labs in 2016, as an attempt to engineer human behavior on a mass scale and drive it to profitable ends. While most of its players thought it was just a "game," Pokémon Go was, in fact, a social experiment intended to lure players into facilities with Pokémons. Based on the theory of operant conditioning, introduced by the $20^{\text {th }}$ century social psychologist B. F. Skinner, the servers of the game predicted what goods its players would most likely buy and made the Pokémons appear precisely at those locations. "The elements and dynamics of the game," writes Zuboff, "combined with its novel augmented- 
reality technology, operate to herd populations of game players through the real-world monetization checkpoints constituted by the game's actual customers: the entities who pay to play on the real-world game board, lured by the promise of guaranteed outcomes" (Zuboff, 2019, chapter 10).

Pokémon Go is only part of a bigger picture of what she calls "machine society," or "the replacement of society with machine action dictated by economic imperatives" (Zuboff, 2019, chapter 7). She writes that surveillance capitalism is "the transformation of the market into a project of total certainty," into which we march "like the smart machines" (Zuboff, 2019, chapter 13). Under this economic system, in which "unpredictable behavior is the equivalent of lost revenue," (Zuboff, 2019, chapter 5) choices are considered to be made not by free and rational individuals, as Adam Smith supposed in his classic views of free market economy, but by programmable, predictable, and controllable "machine-men."

Like Taylorism in the early $20^{\text {th }}$ century, surveillance capitalism is consolidating as a system of interrelated economic and technological factors, in which economic interests result from specific technologies, while technologies, on their part, express economic interests. It must be noted that despite the author describing surveillance capitalism primarily as an economic system, her discussion of it extends beyond pure economics and spreads into the fields of politics, ethics, and philosophy. Just as slavery was more than an economic system, but a condition of human existence based on the denial of freedom, so surveillance capitalism is a new existential condition of non-freedom, which, unlike slavery, operates without chains, handcuffs, or even the knowledge of those whose freedom has been abrogated.

I argue that the challenges it poses to freedom are primarily ethical, because they confront the very foundations of freedom, including the concepts of privacy, autonomy, and authenticity, which I will discuss later in this article. Political, economic, and institutional changes usually affect freedom by increasing or reducing the number of ways in which people can (legally or morally) act in society. The present lockdown, for example, has significantly curtailed freedom by imposing restrictions on many actions, especially those involving face-to-face interactions. The challenge from surveillance capitalism is different, because it does not affect the range of eligible actions, but rather the capacity to act within that range. Therefore, the discussion about it revolves around the ethical and philosophical questions: What is freedom? What value does it have in human society? What is required to be free? These questions are different from the issue of how much freedom there should be in society, which is rather a legal and political one.

The age of surveillance capitalism has been warmly received by reviewers. Some critics, e.g. Kirstie Ball and Sam di Bella, argue that the author has not offered sufficient guidelines on how to mitigate the threats she described (Ball, 2019, p. 254; Di Bella, 2019). Others have underlined the lack of attention to the features of surveillance capitalism in the global South (Evangelista, 2019, p. 247), some simplification of this system's legal framework (Cohen, 2019, p. 242), and giving too little weight to the role of the state in its development (Khan, 2019, p. 737). However, all the reviewers, including the above ones, have praised the book for its deep ethical, philosophical, and sociological insights. Rafael Evangelista argues that at the heart of this piece is the defense of the ethical ideal of freedom against the encroachments of an unprecedented type of power, assisted by new technologies: "The Age of surveillance capitalism," he writes, "is written with the intensity of someone who wants to save a type of subjectivity of the individual, of society, and the dream of freedom that seems to vanish when facing a new type of power" (Evangelista, 2019, p. 249). Before we can proceed to the analysis of how this vanishing happens, let us establish what freedom means for Zuboff.

\section{Shoshana Zuboff's ethical aspects of freedom}

Shoshana Zuboff did not provide a single or straightforward definition of freedom. Instead, she touches on it on many occasions and in relation to the different themes in her book. I suggest 
that her interpretation of freedom revolves around three different, yet interrelated, aspects; privacy, autonomy, and authenticity. These aspects are either directly undermined by the system of surveillance capitalism or are important from the standpoint of its development and functioning.

Freedom as privacy. In Zuboff's analysis, privacy is understood as an essential part of freedom. Although she did not provide a formal definition of privacy, I suggest that she regards it primarily as a personal space, in which an individual can be free from intrusion or overseeing by others. Such an interpretation proceeds from the central theme of her book. According to Zuboff, surveillance capitalism leads to the ongoing dwindling of personal space and the converting of human lives into behavioral data for others' profit. In particular, she discusses how different "smart" technologies, including thermostats and even toys, invade people's houses and act as spying devices, recording the lives of those who dwell inside. The understanding of privacy as the absence of intrusion from others is compatible with Isaiah Berlin's definition of negative freedom (Berlin, 1969, pp. 121-122), but Zuboff also treats privacy as a condition of freedom. She links it with the issue of knowledge possessed about a person by others. The more is known about the person, the more capacity others have in controlling, manipulating, or limiting his / her behavior. Therefore, people who have the least freedom (e.g., prisoners) also have the least privacy. This approach features primarily in her discussion of B. F. Skinner and Alex Pentland, whose views she regards as intellectual underpinnings of surveillance capitalism. These scholars deny freedom as an independent value and argue that it is inversely proportional to the growth of scientific knowledge, while advocating for ubiquitous monitoring of human activities via technologies.

Freedom as autonomy. Zuboff's interpretation of freedom is also very close to the moral ideas of Immanuel Kant. The core concept of Kant's philosophy is human autonomy, which literally means "law onto oneself." Kant argued that human understanding is "autonomous," because it is the source of the general laws of nature that construct our experience. But autonomy is also the central element of his moral philosophy, which is based on the principle of freedom. For Kant, freedom is a type of causality that belongs uniquely to rational living beings. In contrast to natural phenomena, which are subject to deterministic causality, Kant argued that human beings possess an "uncaused cause," which is not subordinate to the deterministic laws of nature. This "uncaused cause" proceeds from the "noumenal Self" within a person and underlies his / her transcendental ability to choose any action (or inaction), even though a plethora of empirical factors (desires, needs, fears, preferences, etc.) may play on their mind at any moment. Kant formulated moral law, which guides freedom, in the famous maxims of his categorical imperative. The categorical imperative facilitates freedom by recognizing its universality and respecting all people as fundamentally valuable "ends in themselves." In Section 3 of his Groundwork of the Metaphysics of Morals, the philosopher argued that despite human freedom of will not being able to be proven empirically, it nevertheless must be postulated, because without it we would not be able to make sense of moral appraisal and responsibility (Kant, 1997, p. 55).

I suggest that Shoshana Zuboff's interpretation of freedom is Kantian because she claims that surveillance capitalism undermines human autonomy and treats human beings basically as commodities. A key principle of this economic system is that digital footprints, which people leave behind as they interact with digital devices, hold clues to their innermost Selves. It is also postulated that by studying these footprints it is possible to manipulate their behavior and steer them to profitable ends. Therefore, surveillance capitalism rejects the crucial Kantian tenet of transcendental "noumenal Self" and regards human beings rather as Humean "bundles of sensations," whose resultant force determines their actions at any moment and which can be manipulated for others' sake. Zuboff argues that human beings possess not only the capacity of will, but also a more abstract faculty of will to will, which she defines as "the inner act that 
secures us as autonomous beings who project choice into the world and exercise the qualities of self-determining moral judgment" (Zuboff, 2019, chapter 9). This definition approximates the Kantian notion of "noumenal Self," which confers upon persons their moral worth. Because we have this capacity, we are also entitled to what she calls "the right to the future tense" (Zuboff, 2019, chapter 11). Surveillance capitalism, which attempts to predict human behavior and put these predictions into use, robs people of their future and shifts control over it from "I will" to "You will." From the Kantian perspective, this shift can be interpreted as a substitution of the domain of freedom, based on the moral law, with the domain of nature, which is based on cause-and-effect relationships and, thus, is deterministic, foreseeable, controllable, and subject to ownership and instrumental use. Throughout her book, Zuboff repeatedly claims that Internet users under surveillance capitalism are stripped of their moral worth and treated as a source of raw material for data mining. She also frequently argues that they have become "a means to other's commercial ends," which I see as a reference to Immanuel Kant's second formulation of categorical imperative (Zuboff, 2019, chapter 16). It must be remarked that Zuboff has made no claim whether or not freedom of will exists, but she postulates it as a vantage point, from which to criticize the project of surveillance capitalism. Thus, she espouses the Kantian idea that human autonomy is the source of morality, which surveillance capitalism blatantly rejects.

Freedom as authenticity. Zuboff's interpretation of freedom has one more aspect, which goes back to the legacy of Romanticism. The understanding of freedom as authenticity, pioneered by Jean Jacques Rousseau, Johann Gottfried Herder, Johann Wolfgang von Goethe, and other figures of European Romanticism, emphasizes the idea that people have unique identities, which must be respected and cultivated. From this viewpoint, freedom is the ability to live one's authentic life and express oneself in unique and genuine ways. In his work The ethics of authenticity, Charles Taylor described this ideal as "a certain way of being human that is my way. I am called upon to live in this way, and not of anyone else's. If I am not, I miss the point of my life, I miss what being human is for me" (Taylor, 1992, pp. 28-29).

According to Zuboff, this dimension of freedom became prominent in the historic period known as the "first modernity." Around two centuries ago, the strict regimentation of human lives by the norms of traditional societies began to unravel, and people gradually obtained freedom to choose their lifestyles and identities for themselves. Despite the "first modernity" formally freeing men and women from once relentless social norms and roles, it simultaneously created new ones. Mass production, sprawling bureaucracies, political ideologies, and allpowerful states suppressed the Self and trapped it in a cold and calculating social system, which Max Weber called the "iron cage." In the 1960s, according to Zuboff, the Western world arrived on the "second modernity," in which "the Self is all we have" (Zuboff, 2019, chapter 2). It was no coincidence that the digital revolution concurred with this historical period. People turned to new technologies, because they offered "new ways to amplify their voices and forge their own chosen patterns of connection" (Zuboff, 2019, chapter 2). Thanks to them, we can foster our authentic ways of life: connect with like-minded people, cultivate our profiles on Facebook and Instagram, express ourselves via Tweets and weblogs, subscribe to our favorite YouTube channels, and do many other things, which express our unique personalities. Freedom as authenticity seems to thrive in the age of the smartphone. Yet, in a paradoxical manner, this freedom serves as a touchstone for the development of surveillance capitalism, which I will consider later in the text.

These three aspects - privacy, autonomy, and authenticity - constitute the bottom line of Shoshana Zuboff's consideration of freedom. Historically, there were different social and political systems that deprived people of their freedom. Totalitarian regimes, slavery, and fanatical theocracies are the first to come to mind. Yet, surveillance capitalism is different from them because it does not operate through violence. In the systems I have just mentioned, 
violence produced resistance, which eventually led to its downfall. However, violence and terror are not the only ways to take away human freedom. In surveillance capitalism, the operational role of violence is replaced by seduction, obsession, delusion, pleasure, and the promise of happiness, making this system closer to Huxley than to Orwell. In the next part of the article, I will consider several ethical challenges to freedom in the framework of surveillance capitalism.

\section{The challenges to freedom under surveillance capitalism}

Just as the reader will not find a single definition of the concept of freedom in The age of surveillance capitalism, he will also not encounter a straightforward list of threats to it. The author touches on them on many occasions while discussing different aspects of this new power leviathan. Therefore, it is necessary to summarize these challenges in the same way as we did regarding the meaning of freedom. To do it, I will take up Zuboff's schema of surveillance capitalism as a conceptual framework. I will not repeat her arguments, but I will attempt to show what challenges accrue from this conceptual framework in a more abstract way. Above I have listed three crucial aspects of freedom: privacy, autonomy, and authenticity. These aspects will also serve as touchstones by which I will interpret the challenges to it.

Challenge to freedom as privacy. According to David Shoeman, privacy "protects social freedom by limiting scrutiny by others and the control some of them have over our lives" (Shoeman, 1992, p. 7). Behavioral surplus, the crucial element of surveillance capitalism, runs against privacy and, ipso facto, freedom. The more information about an individual and his daily routine is incorporated into a prediction model, the more accurately this model will forecast his actions and manipulate his behavior. Manuel Castells argues that privacy has become a new "currency," with which the users pay for their supposedly "free" online services:

Everybody is transformed into data. We are all data and these data are key commodities. The data are at the basis of all the major Internet companies, including Google and others. You are not paying for the service, but you are paying with your data. You are the currency (Castells, 2017).

The bargain whereby someone is paying with his privacy to get something in return is Faustian in nature. Doctor Faust was the protagonist of the $16^{\text {th }}$ century German legend who sold his soul to the Devil, exchanging it for knowledge and worldly delights. Since then, the term "Faustian pact" has been used to describe a bargain whereby a person trades something of supreme moral or spiritual importance for some of worldly or material benefit. Zuboff quotes a new app-based approach to lending as a particularly vivid example of such a pact. According to this approach, a prospective tenant receives a demand from her potential landlord to grant full access to all her social media websites and smartphone activity. This data is then processed by analytical software, which predicts the likelihood of payment default based on such factors as, for example, when and how often she returns phone calls, charges her battery, or how many miles she travels every day (Zuboff, 2019, chapter 5). Although she must formally consent to such a humiliating inspection, those with less money have nothing to do but to accept the deal.

In this case, the motivation to give up one's privacy proceeds from desperation. However, surveillance capitalism exploits a wide range of human emotions to tap into privacy, including amusement, curiosity, pleasure, and others. You can take an online quiz or download an app from Google's Play Market and use it at no cost, but only if you grant access to your contacts, photos, browsing history, geolocation, and other sources of behavioral information. These socalled "surveillance assets" have become so valuable that it is profitable to distribute digital products, including apps and software, very cheaply or for free just to use them as bait for a person's information. 
In the past, everybody had a degree of privacy because there were limits to what technologies could do. Today, due to electronic rendition of virtually all aspects of human experience, decreased privacy and increased control have become two sides of the same coin. Since human lives have largely become computer-mediated, they are being rendered as information. This information, however, does not belong to them. It is being annexed by the companies behind worldwide digitalization, which use it for their corporate goals. Zuboff illustrates how electronic information could be used for social control with the following example.

In the 1980s, scientists who worked at a pharmaceutical company, to which she refers as the "Drug Corp," developed a precursor of today's social media, named DIALOG. It was an early computer conferencing system, which allowed employees to communicate with each other via electronic text. At first, the scientists embraced the new technology and began using it not only for their professional but also for private conversations. Eventually, they discovered that their managers scrutinized every piece of information they shared on DIALOG and had to face some unpleasant consequences. "In a series of conflicts that unfolded over the years," she writes, "I watched as the managers and executives at Drug Corp were simply unable to quell their inclination to use the new social text as a means to evaluate, critique, and punish" (Zuboff, 2019, chapter 9).

Today, billions of people in the world render their lives electronically, while just a handful of companies behind this worldwide digitalization possess an unprecedented ability to oversee and control their actions. The example of Drug Corp is especially expressive today when even more human activities have moved into the digital realm because of the global pandemic. Many employees work remotely and are compelled to use those digital tools, which are prescribed by their bosses. In Ukraine, university departments urge lecturers to use platforms that retain their communications with the students, such as Microsoft Teams, as opposed to those giving more privacy, like Zoom. As a result, there is less freedom of speech and more control from university regulatory bodies. I believe that, in many cases, there will be a temptation to retain these systems of control even after the end of the pandemic.

It should be noted, however, that surveillance corporations have different goals in mind than the managers of Drug Corp. While DIALOG has become a kind of Foucault's panopticon, intended to produce a self-policing and self-censoring individual, the corporations do not intend to punish their audiences, but rather to "hijack" and shepherd them to lucrative ends. I see this hijacking as the next ethical challenge to freedom, namely to freedom as autonomy, which I will discuss next.

It is appropriate to mention, though, that not everybody agrees that the contract whereby privacy is exchanged for something else is "Faustian" by nature. James Bridle, for example, criticizes Zuboff's claim that companies "usurp," "hijack," or "appropriate" people's rights to privacy and self-control. He argues that "people are very willing to give up their private information in return for perceived benefits such as ease of use, navigation and access to friends and information" (Bridle, 2019). In his opinion, this form of quid pro quo is not essentially different from virtually every transaction on the market, and he personally does not seem to find unmitigated legal or ethical troubles accruing from it. I would side with Zuboff, though. Despite people being willing to give up their privacy in exchange for some benefit now, they will not be able to control how their information will be used in the future. Market transactions provide for the possibility of product or payment withdrawal, however, it is impossible to withdraw private information once it has been disclosed to someone.

Challenge to freedom as autonomy. Based on Zuboff, I suggest that this challenge happens in the context of the so-called "machine society." The formation of such a society is a bilateral process whereby human beings become machinelike, while machines, on their part, increasingly come to govern human lives. I believe that Immanuel Kant's moral philosophy provides a valuable framework to assess freedom in the context of the "machine society." 
James Bridle, the British journalist whom I have mentioned above, illustrates the experience of living in such a society:

The alarm beside your bed rings, triggered by an event in your calendar. The smart thermostat in your bedroom, sensing your motion, turns on the hot water and reports your movements to a central database. News updates ping your phone, with your daily decision whether to click on them or not carefully monitored, and parameters adjusted accordingly. How far and where your morning run takes you, the conditions of your commute, the contents of your text messages, the words you speak in your own home and your actions beneath all-seeing cameras, the contents of your shopping basket, your impulse purchases, your speculative searches and choices of dates and mates - all recorded, rendered as data, processed, analyzed, bought, bundled, and resold like subprime mortgages (Bridle, 2019).

Perhaps, I would enjoy living in an environment which has been carefully adapted to serve my daily desires and needs. Maybe I would have done all those routine actions myself, so what is ethically wrong in the fact that these corporations had anticipated my choices and deprived me of some little inconveniency? Zuboff's answer is that such a society would take away the key component of human freedom, namely the autonomous capacity to make conscious decisions based on one's internal "will to will." Unlike animals, humans do not only will things (for example, food or mating partners), but also the will itself. The concept of "will to will" closely resembles the Kantian "uncaused cause," which resides within the "noumenal Self" and confers upon human beings their moral worth. Thanks to this capacity, we belong to the moral "realm of freedom" and not to the deterministic "realm of nature." Zuboff argues that the goal of surveillance capitalism is "not to destroy us but simply to author us and to profit from that authorship." "There is no violence here," she contends, "only the steady displacement of the will to will that has been expressed in the first person voice, and nourished in the kind of sanctuary that depends upon the possibility of private life and the promise of public freedom" (Zuboff, 2019, chapter 11).

It is necessary to emphasize the different nature of the challenges to human freedom, proceeding from surveillance capitalism and "classic" authoritarian systems of power. The latter systems try to subdue the Self through violence. However, even under the most repressive regimes, the Self is still present, although shackled by fear and crippled by indoctrination. Instead, the actions "co-authored" by surveillance capitalists, are no longer determined by the Self. Imagine an authoritarian regime whose leaders bully its citizens to vote for a progovernment candidate. Now conceive that they simply "nudge" them to support that candidate via ubiquitous behavior modification technology. In the words of Chris Wiley, the whistleblower of Cambridge Analytica, the second scenario is worse: "I think it is worse than bullying, because people don't necessarily know it's being done to them. At least, bullying respects the agency of people" (Cadwalladr, 2018). Alex, the protagonist of Anthony Burgess's dystopian novel (and Stanley Kubrick's iconic movie) A Clockwork Orange, is an example of a person whose Self has been "hijacked" through behavioral modification. The title of this piece reveals what type of beings we become in the "machine society" - not autonomous and selfconscious agents, but programmable and predictable "clockwork" entities.

The other part of the bilateral process whereby the "machine society" is constituted is the consolidation of machine agency and its power over human beings. The more we enter into a world where humans are replaced with machine action, the less room there is for freedom. According to Kant, there is no freedom in the realm of nature, or "things" more broadly. You cannot negotiate with gravity or blame the laws of physics for a broken leg. Human laws, on the contrary, can be changed and are subject to moral evaluation. If there is a contradiction between the supreme law of morality - the categorical imperative - and human norms, we, as 
free beings, must act based on the former rather than the latter. Helping the Jews was not legal in the Third Reich. Thousands of them were saved by people of good will who disobeyed orders, risked their lives, and acted in accordance with their innermost principle of moral freedom. There would not have been even a single rescue, however, if the Third Reich had been a "machine society." Had robots executed Nazi commands, none of them would disobey orders, sympathize with their victims, or feel remorse.

Surveillance capitalism exists in the context of the "machine society," or the vast architecture of interconnected and remotely operated devices pre-loaded with hardwired instructions and commands that come to replace humans in an increasing number of spheres. As it happens, freedom gradually becomes expelled from society and replaced by the ruthless determinism of machine action. Zuboff provides an example to illustrate this point.

Pat and Stanford Kipping were an elderly couple from Belleville, Illinois, who could not afford to pay $\$ 95$ leasing fee for their 1998 Buick. Jim Ford, a local repo man, was sent to retrieve their vehicle. Once he arrived, the Kippings invited him in for tea and shared their story. They told Ford that they had missed their payment because they had to buy medicine. Ford was so heartbroken that he waived his repossession fees and volunteered to pay the couple's debt. His response to their misfortune was deeply humane. To act humanly means sometimes to deviate from the determinism of the instruction and heed to one's conscience and moral feelings. Suppose, now, that the car had been pre-installed with a program that would have automatically disabled it in case of delay in payment. Imagine, also, a self-driving vehicle, instructed to drive to a penalty area on its own. Unlike humans, machines would execute any command with which they were programmed. They cannot be invited in for tea and arguing with them is as pointless as arguing with gravity. In a society dominated by machine action there will be less freedom and more of ruthless and implacable necessity.

The view, according to which a person is seen not as a free and moral subject, but as a deterministic automaton whose behavior can be manipulated and changed, has deep roots in Western philosophy, going back to La Mettrie's L'Homme machine [Man a machine] (1747). More recently, it was adopted by the American social psychologist B. F. Skinner whom Zuboff describes as an intellectual precursor of surveillance capitalism. In 1971, Skinner published his controversial book Beyond freedom \& dignity, in which he rejected the notions of "freedom" and "dignity" as antiscientific, obscure, and obsolete terms. According to Vasil Gluchman, "it is important to emphasize that the very title of Beyond freedom and dignity is provocative. It shows the author's fundamental rejection of what he characterizes as traditional literature about freedom and dignity, which shaped the idea of an autonomous person" (Gluchman, 2001, p. 260). In Skinner's view, human behavior is only quantitatively different from the behavior of the rats running through mazes, which he studied in his experiments. He argued that human choices are dictated by a variety of empirical causes beyond their control and recognition and believed that crimes, wars, poverty, drugs, etc., happen because people nourish the belief in freedom and resist the attempts to understand what truly motivates their behavior. Instead, they should reject this ancient "illusion" and submit themselves to a caste of dispassionate scientists and administrators:

Science does not dehumanize man, it de-homunculizes him, and it must do so if it is to prevent the abolition of the human species. To man qua man we readily say good riddance. Only by dispossessing him can we turn to the real causes of human behavior. Only then can we turn from the inferred to the observed, from the miraculous to the natural, from the inaccessible to the manipulable (Skinner, 1976, p. 196).

Before the digital age, it was unclear how behavior modification could be used beyond small, controlled environments. An attempt to adapt Skinner's views to modern circumstances has been made by Alex Pentland, an American computer scientist and entrepreneur with degrees in 
computer science and psychology. In his books Honest signals (2010) and Social physics (2015), he wrote that for the first time in history "we will have the data required to really know ourselves and understand how society evolves" (Pentland, 2014, p. 19). Thanks to Big Data, everything will become predictable and automated - traffic, energy, crimes, infections, political opinions, etc. Big Data, which he calls "the God's eye view," will put an end to the age of "darkness" of mankind. As he writes in Social physics,

Big data give us a chance to view society in all its complexity, through the millions of networks of person-to-person exchanges. If we had a "god's eye," an all-seeing view, then we could potentially arrive at a true understanding of how society works and take steps to fix our problems (Pentland, 2014, p. 11).

Any revolution - and this is definitely a revolution - requires toppling the idols of the past. Like Skinner, Pentland believes that in order to submit ourselves to "the God's eye view," we must stop worshipping the "fetishes" of freedom, privacy, and individuality. A free and sovereign individual, according to Zuboff, has been "an achievement carved from millennia of human suffering and sacrifice. Instead, Pentland brushes it aside as just another debugging of humanity's computer code, a much needed upgrade to the outdated software that is the long human story" (Zuboff, 2019, chapter 15).

It must be emphasized that the parallel with religion in Pentland's quotation does not seem accidental. In Abrahamic religions, God is an omniscient and omnipotent authority. In the Old Testament, he acted in history to achieve his divine plans. In particular, he inflicted ten plagues on Egypt (Exodus 7-11), opened the Red Sea before the Israelites (Exodus 15), and stopped the sun to allow Joshua to win the battle (Joshua 10). These episodes from the Bible can be interpreted as examples of divine "nudging," or the manipulation of contexts to shape the outcomes of behavior, which happens within those contexts. A verse from the Bible also surprisingly illustrates the type of knowledge surveillance capitalism aspires to achieve: "Even before a word is on my tongue, behold, O Lord, you know it altogether" (Psalm 139: 4).

Historically, there have been attempts to secularize the archetype of divine power. For example, Julie Jespersen et al. argue that "with the [Foucault-Bentham] panopticon, God's eye was transformed into a secular context" (Jespersen et al., 2007, p. 112). Richard Hardt and Antonio Negri also contend that just as it is impossible to escape "the eye of God" in religion, the "contemporary control knows no outside. Whereas earlier forms of control had limits, barriers, insides and outsides, postmodern control is an ou-topia, or no-place, formed through circuits of movement" (Hardt \& Negri, 2000, p. 190). Surveillance capitalism seems to continue these endeavors. However, despite the power of God in the Judeo-Christian tradition being absolute and unbounded, it also exalts the human being and endows him / her with freedom, dignity, and moral responsibility. Freedom and morality exist precisely because there $i s$ the ultimate source power, which is God. No morality, however, arises from surveillance capitalism (even the crooked one of the last century's ideologies), which rejects the idea of autonomous person.

Paradoxically, in order to exist, this sociotechnical system requires freedom, but it creates only an illusion of it, which is subverted at the very moment it comes into being. To illustrate this point, let me move to the last ethical challenge to it, namely to freedom as authenticity.

Challenge to freedom as authenticity. As it has been said, this aspect of freedom highlights the right of human beings to emphasize their personhood, foster their unique ways of living, and express themselves in genuine ways. Surveillance capitalism seemingly welcomes this freedom. Whereas privacy, in the words of Mark Zuckerberg, "is no longer a social norm" (Johnson, 2010), and autonomy, according to Alex Pentland, is an illusion inversely proportional to the growth of knowledge, the titans of surveillance capitalism, including Google and Facebook, pretend to be the advocates of authenticity. The so-called "Californian 
Ideology,"espoused, in part, by the Silicon Valley tycoons, is imbued with the counter-cultural attitudes of the 1960s, which advocate diversity and equality. According to Zuboff, surveillance capitalism rose against the backdrop of the shift from the masses to the individual. The explosive commercial success of consumer electronics companies, such as Microsoft and Apple, was largely due to their tapping "into a new society of individuals and their demand for individualized consumption" (Zuboff, 2019, chapter 2). The target audience of these companies were "second modernity" individuals who sought the means of self-expression and emphasizing their unique identities.

Surveillance capitalism encourages individual self-expression and widely distributes technological means for this end. Yet, it also hunts for behavioral data and attempts to control individuals who are mostly unaware that their apps and devices are infested with different kinds of tracking accessories. The paradox of authenticity is that the more people use digital tools for communication and self-expression, the more "digital crumbs" they leave behind, which are used to treat them essentially like marionettes subject to different configurations of behavioral nudges and cues. Thus, according to Zuboff, "the precise moment at which our needs are met is also the precise moment at which our lives are plundered for behavioral data, and all for the sake of others' gain. The result is a perverse amalgam of empowerment inextricably layered with diminishment" (Zuboff, 2019, chapter 2).

This obvious paradox, in my opinion, can be interpreted as the illusion of freedom, emphasized by Fyodor Dostoyevsky. In his novel The Brothers Karamazov, namely the famous Grand Inquisitor part, we encounter a passage that surprisingly resonates with the central theme of Shoshana Zuboff's book:

People are more persuaded than ever that they have perfect freedom, yet they have brought their freedom to us and laid it humbly at our feet. "I don't understand again." Alyosha broke in. "Is he ironical, is he jesting?" "Not a bit of it! He claims it as a merit for himself and his Church that at last they have vanquished freedom and have done so to make men happy. 'For now' (he is speaking of the Inquisition, of course) 'for the first time it has become possible to think of the happiness of men"' (Dostoyevsky).

All the great abandonment of freedom that Zuboff writes about happens because people get something in return - something that makes their lives more comfortable, convenient, pleasurable, and enjoyable, in short, brings them "happiness." People lay their freedom "humbly" at the "feet" of surveillance capitalists, because they make them "happy" by offering countless opportunities to entertain themselves, appease their desires, and serve their needs, including apps, quizzes, mobile phone games, funny pictures, movies, communication, navigation, and all sorts of useful contraptions.

Today, in the words of Dostoyevsky, people have all the reasons to be "more persuaded than ever that they have perfect freedom." Thanks to digital technologies, they have been liberated from the constraints of time, space, borders, and institutions. I can communicate with persons thousands of miles away on Skype, Facebook, and Gmail. I can visit places on the other side of the planet thanks to Google Street View. If something happens anywhere in the world, I will know about it immediately thanks to Twitter. All the while, YouTube, Netflix, and Pinterest offer myriad ways to entertain myself without even the need to go somewhere. All I need to get these wonderful opportunities is a device at a price most people can afford. Isn't it a "perfect freedom"? It would be if it was rooted in autonomy and protected by privacy. Without them, however, the same things that empower individuals simultaneously subdue them. This can be interpreted as an example of Hegel's dialectics, or a thesis-antithesis union: We have these historically unprecedented means of controlling minds and behavior precisely because there is this equally unprecedented freedom. In the industrial age, the same technological advancements that made people freer, compared with the agrarian age (e.g., trains, automobiles, airplanes, 
radio, telegraph), were also used to subdue them, resulting in a system of totalitarian domination, which none of the despots of the ancient world could dream about. Anatoliy Karas argues that the "civic order" of social relationships, which respects the autonomy and dignity of persons, has evolved around the "identification of the meaning of individual freedom and the displacement of the institutions of subordination" (Karas, 2003, p. 11). From this viewpoint, surveillance capitalism is a pushback into the relationships of "subordination,"2 which treat human beings rather as tools than ends-in-themselves. Zygmunt Bauman wrote that our time is marked by "the yawning gap between the right of self-assertion and the capacity to control the social settings which render such self-assertion feasible." In his opinion, "it is from that abysmal gap that the most poisonous effluvia contaminating the lives of contemporary individuals emanate" (Bauman, 2000, pp. 38-39).

Perhaps, the Grand Inquisitor was right, and a "happy" life is indeed more valuable than a "free" life. I will not try to overturn this claim (and even if I wished, I do not know how). I will just quote Yuval Noah Harari who argues that the "freedom vs happiness" dilemma is perhaps more relevant now than it has ever been before, and we are approaching the moment when we will have to choose one of the "horns" of this dilemma - both individually, and collectively: "You might be perfectly happy ceding all authority to the algorithms and trusting them to decide things for you and for the rest of the world. If so, just relax and enjoy the ride. You don't need to do anything about it. The algorithms will take care of everything. If, however, you want to retain some control of your personal existence and of the future of life, you have to run faster than the algorithms, faster than Amazon and the government, and get to know yourself before they do" (Harari, 2018, chapter 19).

\section{Conclusion}

Since the onset of the global pandemic, Shoshana Zuboff's ideas about "surveillance capitalism" have become even more insightful. The amount of physical interactions between people has dropped dramatically, giving way mostly to computer-mediated communications. This potentially can give a big boost to the burgeoning practices of nudging, behavior surplus extraction, and surveillance via digital means. It is possible that many of these systems of control will be retained even after the end of the pandemic. The year 2020 also showed that people can surprisingly easily agree to the reduction of their rights if there is an existential threat, such the virus. Locked in their homes, they can become defenseless before the encroaching leviathan, especially if security, rather than liberty, will be the next political agenda for the coming decade.

However, can does not mean will. I find Shoshana Zuboff's The age of surveillance capitalism a wonderful depiction of the future that can come true if no action is be taken to prevent it. From this viewpoint, despite her book being academic in nature, it is also close to the dystopian novels of Aldous Huxley, George Orwell, Anthony Burgess, Philip Dick, Yevgeny Zamyatin, and other authors who amplified and projected into the future the sociotechnical trends of their time.

Legal and political action must be taken to avert the further materialization of surveillance capitalism. Perhaps the surveillance capitalists will be mandated by law to grant access to their data assets, and the users will be able to customize their profiles, used for ad targeting, for themselves. Maybe, the "surveillance assets" of Big Tech companies will be transformed into a kind of joint-stock company, in which users will be like shareholders, and the companies will lose their exclusive monopoly over the monetization of their private information. In any case, such an action must be preceded by the awareness that the system of surveillance capitalism is ethically wrong.

\footnotetext{
${ }^{2}$ Historical examples of such relationships include slavery, feudalism, racial and gender discrimination, etc.
} 
Individual freedom has been the crucial ethical value in the West for centuries and remains so today. It is the cornerstone, against which people set up their policies to adapt to everchanging political, economic, and technological settings. By putting freedom in the center, we can make sure that the power of man over nature and his fellow beings, which has been greatly extended by modern technologies, will serve the human being rather than someone's egoistic ambitions. Thus, we must be aware of the ethical threats to it in the digital age. The author of this article hopes that it may contribute to this awareness.

\section{References}

BAUMAN, Z. (2000): Liquid modernity. Cambridge: Polity Press.

BALL, K. (2019): Review of Zuboff's The age of surveillance capitalism. In: Surveillance \& Society, 17(1/2), pp. 252-256.

BERLIN, I. (1969): Four essays of liberty. Oxford: Oxford University Press.

BRIDLE, J. (2019): The age of surveillance capitalism by Shoshana Zuboff review - we are the pawns. In: The Guardian, February 2. [online] [Retrieved April 10, 2021] Available at: https://www.theguardian.com/books/2019/feb/02/age-of-surveillance-capitalism-shoshanazuboff-review

CADWALLADR, C. (2018): 'I made Steve Bannon's psychological warfare tool': Meet the data war whistleblower. In: The Guardian, March 18. [online] [Retrieved February 1, 2021] Available at: https://www.theguardian.com/news/2018/mar/17/data-war-whistleblowerchristopher-wylie-faceook-nix-bannon-trump

CASTELLS, M. (2017): Power and counter-power in the digital society. [online] [Retrieved February 1, 2021] Available at: https://www.youtube.com/watch? $\mathrm{v}=\mathrm{io3xwOBD4f0}$

COHEN, J. (2019): Review of Zuboff's The age of surveillance capitalism. In: Surveillance \& Society, 17(1/2), pp. 240-245.

DOSTOYEVSKY, F. (1879): The Grand Inquisitor. From The Brothers Karamazov, trans. C. Garnett. [online] [Retrieved February 1, 2021] Available at: http://fs2.american.edu/dfagel/www/Philosophers/Dostoyevsky/GrandInquisitor1.html EVANGELISTA, R. (2019): Review of Zuboff's The age of surveillance capitalism. In: Surveillance \& Society, 17(1/2), pp. 246-251.

GLUCHMAN, V. (2001): B. F Skinner: For and against freedom and human dignity. In: Filozofia, 56(4), pp. 259-265.

HARARI, Y. N. (2018): 21 lessons for the 21st century. [online] [Retrieved February 1, 2021] Available at: https://philosophiatopics.files.wordpress.com/2018/09/yuval-noah-harari-21lessons-for-the-21st-century.pdf

HARDT, R. \& NEGRI, A. (2000): Empire. Cambridge, MA: Harvard University Press.

JESPERSEN, J. L., ALBRECHTSLUND, A., ØHRSTRØM, P., HASLE, P. \& ALBRETSEN, J. (2007): Surveillance, persuasion, and panopticon. In: Y. de Kort, W. I. Jsselsteijn, C. Midden, B. E. \& B. J. Fogg (eds.): Persuasive Technology: Lecture Notes in Computer Science. Berlin \& Heidelberg: Springer-Verlag, pp. 109-120.

JOHNSON, B. (2010): Privacy is no longer a social norm, says Facebook founder. In: The Guardian, January 11. [online] [Retrieved February 1, 2021] Available at: https://www.theguardian.com/technology/2010/jan/11/facebook-privacy

KARAS, A. (2003): Filosofiia hromadianskoho suspilstva $v$ klasychnykh teoriiakh $i$ neklasychnykh interpretatsiiakh [The philosophy of civil society in classical theories and nonclassical interpretations]. Kyiv \& Lviv: Ivan Franko University Press.

KANT, I. (1997): Groundwork of the metaphysics of morals. Cambridge: Cambridge University Press.

KHAN, A. (2019): Book review: Shoshana Zuboff, The age of surveillance capitalism: the fight for human future at the new frontier of power. In: Social Change, 49(4), pp. 735-738. 
PENTLAND, A. (2014): Social physics: How good ideas spread - the lessons from a new science. New York: Penguin Books.

ROHLF, M. (2020): Immanuel Kant. In: Stanford Encyclopedia of Philosophy. [online] [Retrieved February 1, 2021] Available at: https://plato.stanford.edu/entries/kant/

SHOEMAN, F. D. (1992): Privacy and social freedom. Cambridge: Cambridge University Press.

SKINNER, B. F. (1976): Beyond freedom \& dignity. London: Pelican Books.

TAYLOR, CH. (1992): The ethics of authenticity. Cambridge, MA: Harvard University Press. THALER, R. H. \& SUNSTEIN, C. R. (2003): Libertarian paternalism. In: The American Economic Review, 93(2), pp. 175-179.

ZUBOFF, S. (2019): The age of surveillance capitalism: The fight for a human future at the new frontier of power. New York: PublicAffairs. [online] [Retrieved February 1, 2021] Available at: https://we.riseup.net/assets/533560/Zuboff\%2C+Shoshana. The+Age+of+Surve illance+Capitalism.2019.pdf 